\title{
READING AND WRITING HISTORICAL FICTION
}

Susan Peabody

WHEN I WAS hired as a temporary library employee a few years ago, my supervisor asked me during the job orientation, "Do you know the difference between fiction and non-fiction?" I stammered, tonguetied for a few moments, until I realized that she was asking a simple yes-or-no question, not demanding an air-tight philosophical definition. I finally responded, "Yes, I do," but I was left with the lingering suspicion that I had lied.

This paper is a tentative exploration into the genre which spans the bridge between fiction and non-fiction, the historical novel. For the purposes of library classification, the historical novel is shelved with other fiction. But its placement is ambiguous. Many commentators observe that the general public is more likely to learn about the past from historical fiction than from "straight" history (e.g., Tebbel; Aiken). Some writers, such as Gore Vidal, will go so far as to say that their fiction is "fact." Finally, recent techniques of literary criticism have made some readers, beginning with Roland Barthes and Hayden White, question the boundaries that separate history from fiction. History's status as an independent genre seems to be threatened by modern notions of relativism. Historical fiction, with its ambiguous relationships to both history and fiction, might be a good starting place for an analysis of the claims of both kinds of writing.

For the purposes of this essay, I have limited my analysis to what might be called "high brow" historical fiction of the 1980s. By "high brow," I mean historical fiction written for a predominantly collegeeducated readership. In this essay I will not attempt to deal with the sub-genre of historical romances. This is not because I think that problems raised by this form are uninteresting. Indeed, a study of the reading and writing of the so-called "bodice-rippers" and their uses of history, could prove fascinating. Rather, I have decided to omit this 
more popular literary form because of the relative difficulty of obtaining statements from authors and readers about their respective processes.

To analyze the creation and reception of the contemporary historical novel, I have studied statements by readers and authors of historical fiction-in interviews, reviews, letters and essays-about the processes of reading and writing. ${ }^{1}$ I have paid attention to what reviewers feel are the successes and failures of individual works, for these statements show us their criteria of judgement. I have listened carefully to their overt discussions of the differences between history and fiction, and I have queried authors about what they feel those differences are. The conversation between readers and writers shows that there are three overlapping areas of concern. One of these is the contrast between what might be called the historian's efforts to illuminate and the novelist's proclivity to conceal. Another issue is the supposed ability of the successful historical novel to "make the past come alive." Finally, there is the relationship between these issues and the question of narrative point of view.

Although I might start with any of these, let me begin with the issue of illumination versus concealment. I begin with the assumption that the historian's objective is to shed light on the past "as it really was." Historians may disagree profoundly with one another about what actually happened, and why things happened that way, but they generally agree that their purpose is to find out, and reveal to others, as nearly as possible, the "truth" about the past (e.g., Veyne 11). A typical historical narrative tells its readers what was the case and why it was the case. A historical account does not attempt to hide things from its readers. The notion of suspense does not enter into the reading or writing of an historical work.

This is a marked difference from the conventions of contemporary historical fiction. Novels such as Umberto Eco's Name of the Rose and Toni Morrison's Beloved create an atmosphere of suspense which compels the reader to follow the narrative to the conclusion where a secret is revealed. The Name of the Rose is a detective mystery set in the Middle Ages. The question "whodunnit?" is what propels the reader through all 502 pages. The secret in Beloved concerns the title character and her relationship to the other characters in the book. The convention of secrets is so strong in this book that two reviewers, Rosellen Brown and Margaret Atwood, refused to give a complete description of the plot so that they would not spoil it for their readers.

The suspense present in these two novels is not immediately apparent in Gore Vidal's Lincoln, where the ending, Lincoln's assassination, is presumed to be known in advance by the reader. A subtler 
sense of secrets, however, is in operation here. Vidal hides little jokes, to delight the knowing reader, such as the fictitious character "William de Touche Clancy" who appears in Vidal's other novels. One reviewer who spotted Clancy observed:

[Vidal] insists that the character is fictional, [but] those who know him will point to the similarities in all but promiscuity, syphilis and homosexuality to one of Vidal's deadly enemies. (Edwards)

We are still left to wonder, "Who is Vidal's enemy?" Part of the pleasure of reading is unlocking this personnage a clef. John Vernon plants a similar secret in his novel, La Salle, to be discovered by readers who are "in the know." Toward the end of the book is a playwithin-the-novel written by the character La Salle for his colonists to perform. Vernon writes that:

On page 151 of the novel, the first two lines of La Salle's play are taken from Emily Dickinson's poem \#870.... And the name of the minstrel in the play, Eliym, is an anagram of Emily. These are the little jokes that novelists play. (Letter)

The librarian of Umberto Eco's labyrinthine library is Jorge of Burgos (after Borges, the contemporary novelist who has described a similar library in his fiction). One reviewer also spotted a paraphrase of Ludwig Wittgenstein's Proposition 6.54 of the Tractatus in The Name of the Rose. In the novel, the quotation is attributed to "a mystic" from Germany. Discovering these little jokes is one of the sophisticated reader's pleasures in fiction.

A pleasure which is perhaps unique to the reading of historical fiction (as opposed to purely imaginary fiction) is the reader's ability to identify the author's sources. My friend, Beth Nachison, an avid reader of historical fiction, told me that this is one of the qualities she enjoys:

When I'm reading a historical novel in a period that I know something about, it's always a treat if I can read something and say, "Aha! I know where they got that!"2

Historical fiction, unlike history, is not constrained to cite its sources with footnotes in the text. Thus the reader experiences the pleasure of discovery when she finds something familiar. ${ }^{3}$ A fiction writer who borrows too heavily from source material, however, may be castigated for being unable to "digest his material, to integrate it into his book" (Hoffman). One reviewer found this to be such a problem with Vidal's Lincoln that he could no longer call it a novel. ${ }^{4}$

Thus, on several levels, the writer of historical fiction may hide things from the reader, whose pleasure is partly derived from discovering them for himself. This discovery makes the reader feel intelligent, "in the know." Historians, by contrast, "illuminate" the past and their readers learn from the text. The explanatory aspect of history is part of the historian's method of illumination. Historians 
recount certain facts and events in their writings and offer explanations of these events. The expectation that a text will explain the past is so prevalent among historians that they sometimes look for historical arguments in works of fiction. One reviewer (a biographer) wrote that Toni Morrison's Beloved "means to prove that Afro-Americans are the result of a cruel determinism" (Crouch). The passage which he cites as an example reads more like a character's internal stream of consciousness than any kind of "proof." Another reviewer of Lincoln, a historian, refers twice to Vidal's "argument":

The book Lincoln does not make a case for that cosmo-politanism of the old South, but it does clearly argue that an old order was swept away by the Civil War. (Edwards 38)

The delivery of [the Gettysburg address] is one of the brightest, hardest gems of the book and Mr. Vidal vigorously supports his argument that the text was a little different from the common form now regurgitated. (Edwards 40)

Again, Vidal does not set out to "argue" anything. The novel depicts the old South being swept away and shows that the text of the Gettysburg address differs from its present version. Another historian totally misunderstands the literary device in which the story is told from the various characters' points of view and attributes those characters' statements to Vidal himself (Current; see also Vidal's response). I shall return to this question of point of view later.

Fiction writers operate under the dictum, "show, don't tell." The need to explain an event in the story is seen as a failure of the novelist's art. For example, a friend's novel-in-progress concerns a detective in 1902 who is sent to a small town in Iowa to collect evidence against a saloon operating in violation of the state prohibition laws. In the end, a mob of townspeople chases the detective into the prairie in the dead of winter where he nearly dies of exposure. I asked my friend, Scott Hewitt, if he would need to explain in the novel why the townspeople attempted to lynch the detective. He responded:

It should be obvious. The explanation is the events leading up to that. There's no narrator's voice in this story. There are only the voices of the people. The explanation is what happens before that that leads up to that. . . A fiction writer dramatizes it happening. I'm not explaining because all the events are right there in living color explaining why, that is, how something happened, and why it happened. (Interview)

Both the historian's misunderstanding, above, and Hewitt's account of the lack of explanation in fiction raise the question of narrative point of view. Before I take up this topic, I want to discuss another one of Hewitt's remarks: that fiction places the events "right there in living color." 
... [The pleasure of historical fiction is] not so much to see where [history and fiction] melt, but to try to make the past "live again" to use a trite phrase. To take all these dead facts - the kings and battles and details of shipping cargoes - and to put people into them; wind their springs and let them walk around (Nachison).

This book [Lincoln] illumines what I had thought a familiar chapter of history, recaptures and fleshes out a remarkable man and his contradictions.... (Whitehead)

Eco has set into motion - fantastical though that motion may be-a piece of an old tapestry. (Birkerts)

Readers of historical fiction bring several criteria of judgment to the reading of a historical novel. Foremost among these is that the historical novels should provide accurate, convincing portraits of the people of the past; in short, it should "make the past live." fill their assessments with words and phrases like "recreates," "sets into motion," and "fleshes out." What is this quality of "bringing to life" and how does the historical novel do it?

In the Rhetoric, Aristotle urges orators to make use of metaphor because of its capacity to render a scene "before our eyes." He says that metaphor makes the hearer "see things": "By "making them see things' I mean using expressions that represent things in a state of activity." According to Aristotle, metaphor has the ability to give "metaphorical life to lifeless things: all such passages are distinguished by the effect of the activity that they convey" (Rhetoric 1410:10-13; 1411:24-26).

But the most important function of the metaphor, Aristotle says, is to help get across new ideas to one's listeners:

We all naturally find it agreeable to get hold of new ideas easily: words express ideas, and therefore those words are the most agreeable to us that enable us to get hold of new ideas. Now strange words simply puzzle us; ordinary words convey only what we know already; it is from the metaphor that we can best get hold of something fresh. (Rhetoric 1410: 10-13; emphasis added)

Metaphor, suggests Aristotle, is an effective way to make the strange familiar, to help us learn new ideas easily. There is a striking similarity between Aristotle's discussion of metaphor and readers' and writers' expectations of the historical novel. For example, Vernon remarks in his letter about La Salle:

I wanted to show what the pictures we see in textbooks of early explorers (with their clean faces, elaborate costume, shining weapons, neat flags, natives in rows-all idealized and antiseptic) don't show - the lice, the fatigue, the continual closeness of death, the dysentary, the cold, the discomfort, the loss of orientation, the dirt, the grease for a meal three times a day, the annoyance, the boredom, the hunger, the fear, etc.

At least one motive for writers of fiction, then, is to give a convincing portrait of the people, ideas, and circumstances of living in the past. 
This corresponds to another reason for reading historical fiction. Besides the pleasure of discovery discussed above, some readers find that the historical novel satisfies the desire to learn something about the past. Beth Nachison told me that she sometimes reads a novel about an unfamiliar historical period to get acquainted with the important characters and issues before she turns to the academic historical writings. Similarly, reviewers often mention the capacity of historical fiction to instruct readers about the past. ${ }^{6}$

The historical novel acts, in some ways, as a metaphor for the past. Through the novel, the past is portrayed as a visual scene, a drama, which the reader can understand. The past is animated in a way that conventional history is (apparently) unable to do. Richard N. Current, reviewing Vidal's Lincoln (rather unfavorably) suggests why this may be true:

Though aiming at objectivity or authenticity, a historian or biographer sometimes misses because distracted by thoughts of literary effectiveness. ... [T] here may be a temptation to emulate the novelist to the extent of presenting occasional scenes in lifelike detail. For each detail, perhaps no more than a single source can be found, and to depend on that one source is to violate the historiographical requirement of two or more independent witnesses. This requirement accounts for much of the dry-as-dust quality that the work of academic historians is presumed to have: they are constrained to write what amounts to the lowest common denominator of the widest variety of sources. (87)

This passage links together several important notions: "literary effectiveness" has the potential to undermine objectivity or authenticity; the novelist presents scenes in "lifelike detail"; the historian operates under a constraining requirement of confirmation of sources; and finally, this requirement creates the "dry-as-dust" quality of academic historical writings.

This passage is especially interesting because it highlights two important differences between history and fiction: the use of "historical detail" and the question of point of view. I will address the notion of "historical detail" first.

Hewitt, in the course of writing his novel, has run into the problem of the authenticity of historical details:

Those kinds of details create a sense of background "texture" which, in fact, very much inform the plots, and themes, and characters and all that kind of stuff. You can't have a really real character in 1902 unless that character is really aware of what someone would be aware of in 1902: everything from what kind of shoes you wear to how you do your crops in the summer. (Interview)

At other times he stresses that he would like to ignore the background "texture" (at least in his first draft) and concentrate on "doing the job of fiction," but to do so would be to threaten the believability of his novel. The background texture is intimately caught up in the themes, setting, and characterizations of his novel. Hewitt, unlike 
Vidal, has some leeway in that all his characters are imaginary and thus not tied to specific documents of the past, but he worries that the wrong details will undermine the atmosphere of authenticity that his novel strives to produce. This dilemma has caused him to think about alternatives to the historical novel:

I've thought about making it a contemporary novel because at times the problem of historical detail has been such a large one that I've thought, "Well, maybe I should just make it now." But that wouldn't work because I like the idea of this town being really isolated -these people are really out there on their own. . . There's no telephones there. There's no electricity; there's hardly anything. It's a bunch of farmhouses scattered around in the same general area. (27)

The background details of turn-of-the-century rural society are necessary for Hewitt's themes of isolation. The stark, empty landscape of the Iowa winter is a metaphor for the still emptiness of mind that his main character seeks. The themes of emptiness and purity recur in the symbolic details Hewitt has selected for his narrative.

One of the ways that historical fiction connects the present to the past is through theme. One reviewer objects to the themes of Beloved that may be clearly recognized as prevalent concerns in our own present culture:

The book's beginning clanks out its themes. . . There is the theme of black women facing the harsh world alone. Later on in the novel, Morrison stages the obligatory moment of transcendent female solidarity. ... Then there is the sexual exploitation theme. (Crouch 42)

In The Name of the Rose many readers recognize familiar issues of the present in Eco's rendition of the past.

In the fate of the monastery and library, the 20th century reader may see reflected his own apprehensions as to the future of his world and his culture, and, in the failure of Brother William's chain of reasoning, his own inability to order history. (Hartley 39)

... [i]ts title, The Name of the Rose, states one of its central themes, the troubling relation of names and things, language and reality... . Throughout the novel the fourteenth and twentieth centuries are not so distant mirrors of each another. (Ahern)

Through this notion of theme, then, the historical novel posits the similarities between the past and the present.

The metaphor joins together two otherwise dissimilar things by virtue of their shared attributes. According to Aristotle:

The greatest thing by far is to be a master of metaphor. It is the one thing that cannot be learned from others; and it is a sign of true genius, since a good metaphor implies an intuitive perception of the similarity in dissimilars. (Poetics 1459:5-8)

Paradoxically, John Vernon asserts that his novel also attempts to make experience "come alive" not by rendering it familiar, but by making it strange. 
I wanted to do what all fiction should do: to renew our acquaintance with experience by de-domesticating it, by making it strange again. History seems the perfect field in which to do this: it too must be cleansed of stereotypes and made strange again, if we are ever to succeed in re-imagining it again. (Letter)

His statement is ambiguous; it implies that fiction should render not only the past strange but the reader's present as well. According to Merle Rubin, this is also an effect of Eco's novel. The narrative strategy of The Name of the Rose makes its readers aware of the newness of scientific thinking:

For many of us, heirs to the Enlightenment, the process by which we formulate and test hypotheses seems "only natural." It is anything but. By setting his story at a time when other forms of thought prevailed, Eco re-creates a sense of the difficulty and challenge of the method we take for granted.

Hence, this metaphorical quality of the historical novel has the capacity both to render the past familiar and to make the present seem strange. Its "animation" derives, in part, from its ability to reveal the apparent similarities between the past and the present.

$$
* * * * *
$$

A striking similarity between the novels I read for this essay is that each is written from the point of view of one or more characters within the story. The convention of telling a story from a point of view other than the author's is not new or surprising in fiction. In academic historical writing, however, this convention is unheard of. Indeed, if one were to try to write a work of history from a point of view which differed substantially from the author's, it would no longer be called "history," but fiction. One can imagine the furor that such an attempt would raise within the discipline. ${ }^{7}$

This is not to say that authorial voice of a historical text is somehow "authentic," or devoid of convention. In fact, the relative uniformity of syntax and style of historical writings (when compared to fiction) suggests that the historical narrative voice is an artificial construction designed for different purposes than fictive narrative voices. Certain conventions of historical narrative restrict the historian's point of view. For example, it must appear impartial and objective (avoiding frequent use of the first person). A fiction writer has more freedom: she can choose to tell the story through an omniscient third-person narrator (similar to the historian's), through a single character from the story, or through several characters (as in the epistolary form of $L a$ Salle).

Hewitt suggests that the ideal of fiction is for the narrative to erase the sense of an author entirely. He recalls Annie Dillard's work, Living by Fiction, 
where she talks about ... a few, just the greatest works of all literature, in which ideas have completely disappeared into objects. Where there's a certain tension in things which is so perfect that you can't figure out "what the author is trying to say" because the author isn't there. The author has completely disappeared. This idea of ideas completely disappearing into objects means that there are no explanations, there is only exactly what you see in the story. And in the great works those ideas, those explanations, are embodied in those objects. In other words the writer has picked his symbols, picked his objects, because they're the best possible ones to suggest those explanations. (Interview)

For Hewitt, in an ideal piece of fiction things seem to speak for themselves. Things which speak for themselves require no explanations, no author.

Perhaps point of view is the most important difference between history and historical fiction. A work of history must be written from a point of view which represents the actual author's. The author's voice tells the reader what happened and why it happened. Without this association between the actual historian and the narrative perspective of the text, the historian could not be held responsible for her argument. Her argument constitutes her identity as a historian in the academic community. Without it, she ceases to exist for the discipline.

In historical fiction, the writer may tell the story from the point of view of real or imaginary characters, thus appealing to the reader's imagination. When this is done well, the past appears to "live" and the present is made strange. Historical novels function structurally as a metaphor, joining the past with the present, and the reader with the author, emphasizing their mutual similarities and differences. Perhaps professional history also functions metaphorically, but its disciplinary conventions and rhetorical structures seem to weaken the vividness and immediacy that we find in the best historical fiction.

\section{NOTES}

1. The interviews and reviews focused primarily on six works: Gore Vidal's Lincoln; Umberto Eco's The Name of the Rose; Toni Morrison's Beloved; John Vernon's La Salle; Norman Mailer's Ancient Evenings; and Scott Hewitt's novel- in-progress, February, 1902. Certain publications have been especially useful for my purposes. The reviews published in the New York Review of Books, The Nation, The New Republic, Encounter, The New York Times Book Review, and the Christian Science Monitor tend to be lengthy, in-depth discussions of most of the novels in question.

2. Beth has read over two hundred historical novels and is currently writing one of her own. She was extremely helpful to me as I researched this paper.

3. Something similar occurs in a work of history when the author refers to other literature in the field by its subject, but without citing it directly in a footnote. A reader who is familiar with the literature may feel satisfied to recognize a reference which would pass over a less initiated reader's head. But if this goes too far, it can be considered plagiarism. The historical novelist, by contrast, is expected to borrow from the historical record without citing her sources.

4. "A novel it isn't, if by a novel one means a work of the imagination, a piece of fiction, 
a fable, a story, an invention" (Hoffman).

5. These views are so pervasive that a single novel can be judged by different readers both to have and lack these qualities. For example, compare: "Vidal makes famous names-Seward, Chase and his ever-scheming daughter, Kate, McClennan and Grant, Sumner-come believably alive" (Michaud 1146), and "... the father and daughter who appear in [Lincoln] are not nearly as engrossing as the real items. By the same token the spidery, conniving Edwin Stanton, Secretary of War, is a pale copy of the original" (Hoffman 744).

6. See, for example, Blue 32, Turner 667, Birkerts 38, Brown 419, and Bloom 3.

7. The hostile reaction of some historians to Vidal's novel seems to derive in part from Vidal's assertion in the afterward that, "All of the principal characters really existed, and they said and did pretty much what I have them saying and doing ..." (Qtd. in Current, 79). Had Vidal stuck with his subtitle, "A Novel," it is doubtful that he would have raised such a ruckus with the historians but his statement here encourages historians to judge him by the narrow rhetorical standards of their own field.

\section{WORKS CITED}

Ahern, John. Rev. of The Name of the Rose, by Umberto Eco. Commonweal 110 (1983): 597.

Aiken, Joan. "Interpreting the Past: Reflections of an Historical Novelist." Encounter 64 (May 1985): 37-43.

Aristotle. Poetics. Trans. Ingram Bywater. The Rhetoric and the Poetics of Aristotle. New York: Modern Library, 1984.

Aristotle. Rhetoric. Trans. W. Rhys Roberts. The Rhetoric and the Poetics of Aristotle. New York: Modern Library, 1984.

Atwood, Margaret. Rev. of Beloved, by Toni Morrison. New York Times Book Review 92 (13 Sept. 1987): 1, 49-50.

Birkerts, Sven. Rev. of The Name of the Rose, by Umberto Eco. New Republic 189 (5 Sept. 1983): 38.

Bloom, Harold. Rev. of Ancient Evenings, by Norman Mailer. New York Review of Books 28 April 1983: 3.

Blue, Adrianne. Rev. of Lincoln, by Gore Vidal. New Statesman 108 (28 Sept. 1984):32.

Brown, Rosellen. Rev. of Beloved, by Toni Morrison. The Nation 245:418-21.

Crouch, Stanley. Rev. of Beloved, by Toni Morrison. New Republic 197 (19 Oct. 1987): 42.

Current, Richard N. "Fiction as History: A Review Essay." Journal of Southern History 52 (1986): 77-90.

Eco, Umberto. The Name of the Rose Trans. William Weaver. New York: Harcourt, 1983.

Edwards, Owen Dudley. Rev. of Lincoln, by Gore Vidal. Encounter 64.1 (Jan. 1985): 36-40.

Hartley, Anthony. Rev. of The Name of the Rose, by Umberto Eco. Encounter 62 (March 1984): 39.

Hewitt, Scott. February, 1902. Unpublished.

Hewitt, Scott. Personal interview. 20 March 1988.

Hoffman, Nicholas Von. Rev. of Lincoln, by Gore Vidal. The Nation 238 (1984): 744.

Mailer, Norman. Ancient Evenings. Boston: Little, 1983.

Michaud, Charles. Rev. of Lincoln, by Gore Vidal. Library Journal 109 (1984): 1146.

Morrison, Toni. Beloved. New York: Knopf, 1987.

Nachison, Beth. Personal interview. 22 March 1988. 
Rubin, Merle. Rev. of The Name of the Rose, by Umberto Eco. Christian Science Monitor 2 Dec. 1983: B6.

Tebbel, John. Fact and Fiction: Problems of the Historical Novelist. Lansing: Historical Society of Michigan, 1962.

Turner, Edith. Rev. of The Name of the Rose, by Umberto Eco. Commonweal 110 (1983): 667.

Vernon, John. La Salle. New York: Viking, 1986.

Vernon, John. Letter to the author. 18 March 1988.

Veyne, Paul. Writing History. Trans. Mina Moore Rinvolucri. Middletown, CT: Wesleyan UP, 1984.

Vidal, Gore. Lincoln: A Novel. New York: Random House, 1984.

Vidal, Gore. Question about his novel Lincoln at the National Press Club Luncheon. National Public Radio. 16 March 1988.

Vidal, Gore. Response to Richard Current. New York Review of Books 28 April 1988: 56-58.

Whiteland, Phillip. Rev. of Lincoln, by Gore Vidal. Listener 112 (27 Sept. 1984): 31. 